\title{
SCREENING OF TOXIC MARINE NITZSCHIA SPECIES (BACILLARIOPHYCEAE) IN MALAYSIA
}

\author{
Suriyanti Su Nyun Pau ${ }^{1 *}$, Dzulhelmi Muhammad Nasir ${ }^{2}$, Gires Usup ${ }^{1}$ \\ ${ }^{1}$ School of Environmental Science and Natural Resources, Faculty Science and Technology, \\ Universiti Kebangsaan Malaysia, 43600 Bangi, Selangor, Malaysia \\ ${ }^{2}$ Institute of Biological Sciences, Faculty of Science, Universiti Malaya, 50603 Kuala Lumpur, \\ Malaysia \\ *Corresponding author e-mail: sue_0586@yahoo.com.my
}

Submitted: 23 February 2017 / Revised: 23 February 2017 / Accepted: 26 April 2017

http://doi.org/10.21107/jk.v10i1.2635

\begin{abstract}
Amnesic Shellfish Poisoning (ASP) is a type of intoxication caused by the neurotoxin domoic acid (DA). The diatom genus Nitzschia is capable of producing this toxin. Screening for the presence of toxic Nitzschia spp. was carried out at various estuaries in Malaysia. Nitzschia-like cells were isolated and established into clonal cultures. Late stationary phase of cultures were harvested and tested for toxin production using HPLC. Toxin production and compound was verified by LC-MS. From the analyses, at least three cultures were detected with $D A$, while the rest of the cultures did not show detectable amounts of DA. The localities of the toxic species are Johor and Sabah. Here we conclude that toxic Nitzschia species are present in Malaysian water.
\end{abstract}

Keywords: diatom, estuary, intoxication, safety, toxic

\section{INTRODUCTION}

Domoic acid (DA) is a neurotoxin produced by the diatom Pseudo-nitzschia sp. that cause Amnesic Shellfish Poisoning (ASP) in Prince Edward Island, Canada in 1987 (Bates et al. 1989). The toxin accumulates in shellfish among others where signs of intoxication include memory loss in human (Perl et al. 1990) and even fatality in mammals (Scholin et al. 2000) and birds (Fritz et al. 1992). Recent studies had discovered DA producing capability in the genus Nitzschia (Kotaki et. al. 2000; Smida et al. 2014).

Eventhough HABs in Malaysia have always been attributed to dinoflagellates (Roy, 1977; Ting and Wong, 1989; Usup et al., 1989; Usup et al., 2002), the nation is susceptible to ASP outbreak as toxic Nitzschia sp. is widely distributed in Asia (Kotaki et al., 2004). Thus, we took the effort to screen for toxic Nitzschia species focusing on the marine water of Malaysia.

\section{MATERIALS AND METHODS}

Sample collections and culture
establishments

Phytoplankton samples were collected at various estuaries in Malaysia (Figure 1) using a $20 \mu \mathrm{m}$ mesh size plankton net between March 2012 and October 2014. Live samples were brought back to the laboratory for further processing. Nitzschia-like cells were isolated using a finely-tipped micropipette into 96-well plates. Healthily divided cells were transferred into culture tubes containing silica-enriched SWII media (Iwasaki, 1961) and maintained at $26{ }^{\circ} \mathrm{C}$ in $14: 10$ light:dark cycles. 


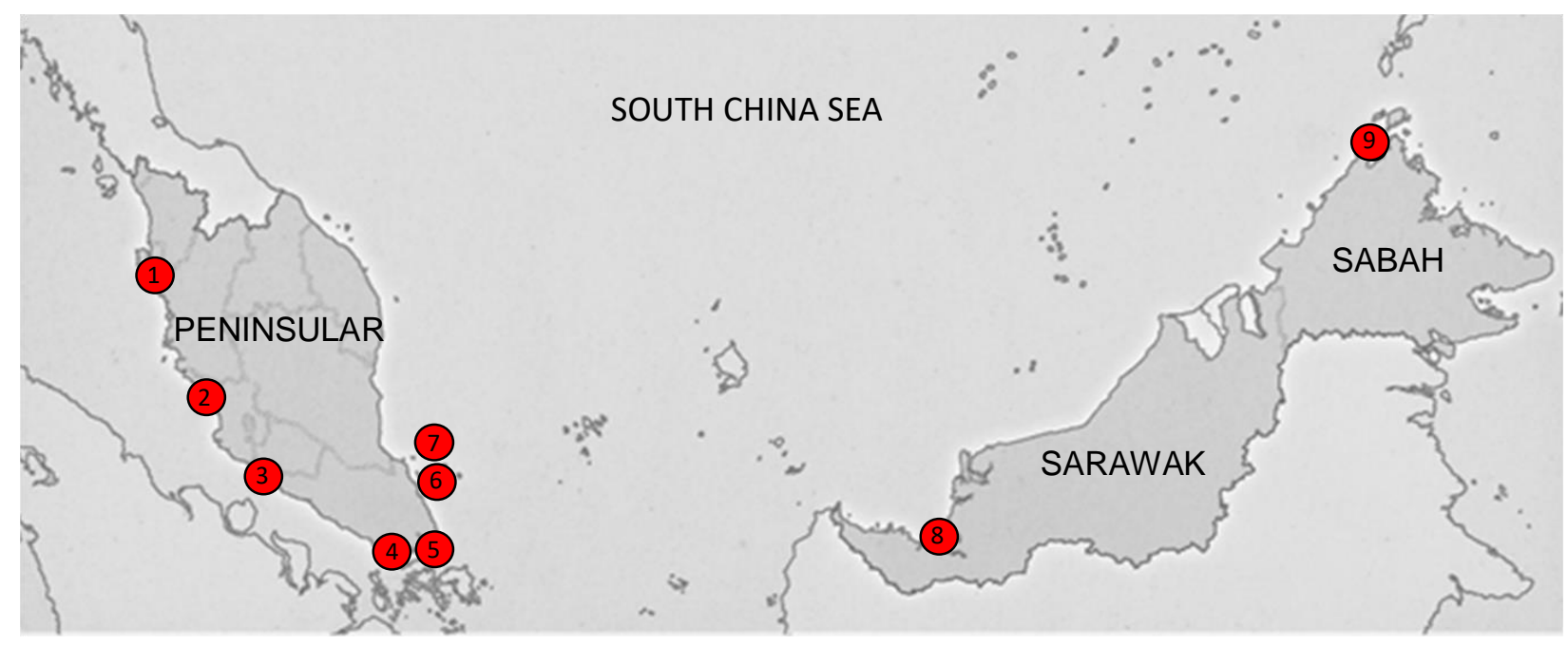

Figure 1. Map of Malaysia. Phytoplankton collections at different estuaries

\section{Screening for ASP toxin}

One liter of Nitzschia cultures were harvested after 30-days by manual filtration over $20 \mu \mathrm{m}$ sieves. Harvested cells were transferred into $1.5 \mathrm{~mL}$ microcentrifuge tubes. Domoic acid extractions and HPLC-UV (Shimadzu Corporation, Japan) conditions were carried out according to the Manuals for Determination of Marine Biotoxins Protocol for ASP toxins. Extracts with detected toxin production were verified using LC-MS micrOTOF-Q (Bruker, Germany).

\section{RESULTS AND DISCUSSION}

\section{Cultures and screening}

Out of 106 total isolates from all locations, only 12 were successfully established into cultures (Table 1). Other isolates were either did not survive in isolation wells or were other diatoms instead of Nitzschia species. Kudat has the most culture strains followed by Kuala Selangor. All other locations were represented by at least 1 culture strain, except for Santubong, Sarawak where none of the isolates survived. Seven cultures are marine origin while 6 were isolated from mangrove areas. Three from 12 culture strains analyzed using HPLC analysis had a peak corresponding to domoic acid (data not shown).

Table 1. Localities and habitats of culture strains tested for toxin production.

\begin{tabular}{clllc}
\hline No & Locality & Culture & Habitat & Toxin test \\
\hline 1 & Teluk Kumbar, Penang & TK47 & Marine & - \\
2 & Kuala Selangor, Selangor & KS58 & Mangrove & - \\
& Kuala Selangor, Selangor & KS55 & Mangrove & - \\
3 & Port Dickson, Negeri Sembilan & PD1 & Marine & - \\
4 & Sungai Pendas, Johor & P22C7 & Mangrove & + \\
& & P22G9 & Mangrove & + \\
5 & Teluk Sengat, Johor & NTS105 & Mangrove & - \\
6 & Pulau Sibu, Johor & PS8 & Marine & - \\
7 & Pulau Tioman, Pahang & TMN26 & Marine & - \\
8 & Santubong, Sarawak & n.d. & Mangrove & - \\
9 & Kudat, Sabah & KD89 & Marine & - \\
& Kudat, Sabah & KD92 & Marine & - \\
& The Tip of Borneo, Sabah & TOB54 & Marine & - \\
\hline
\end{tabular}

nd: no data; (+) DA detected; (-) DA undetected. 
Little study has been done on this genus as the taxonomy of this diatom is very complex particularly for those who have the limited access to electron microscopy and literatures. There are more than 500 described species of Nitzschia and some of them are still being reclassified and verified (Guiry and Guiry, 2014). So far, there are two toxic species in the genus, namely N. navisvaringica Lundholm et Moestrup and $N$. bizertensis Smida, Lundholm, Salda, Hadj Mabrouk. Toxic Nitzschia species is widely distributed in temperate to tropical water including Vietnam (Kotaki et al. 2000; Lundholm and Moestrup, 2000), Japan (Kotaki et al., 2004), the Philippines (Kotaki et al., 2005; Bajarias et al., 2006), Thailand (Romero et al., 2008), Indonesia (Romero et al., 2011) and Tunisia (Smida et al., 2014). Previous study done in southern parts of Asia which included several sites in Malaysia reported that toxic Nitzschia species was rare due to unfavourable environmental conditions (Thoha et al., 2012). This study focuses on estuarine areas as toxic Nitzschia species were reported from brackish to marine areas (Kotaki et al., 2000; Lundholm and Moestrup, 2000; Kotaki et al., 2004; Kotaki et al., 2005; Bajarias et al. 2006; Romero et al., 2008; Romero et al., 2011; Smida et al., 2014). More species are expected if extensive sampling is carried out at locations we did not cover.

\section{Toxin profiles}

In LC-MS analyses of all toxic strains, a peak at the same retention time as DACS-1D standard was observed (Fig. 2a and b). The MS of the substance showed an ion peak at $\mathrm{m} / \mathrm{z} 312$ which is the $[\mathrm{M}+\mathrm{H}]^{+}$of DA (Fig. $2 \mathrm{~b}$ and $c$ ). The highest relative toxin intensity is from P22C7 culture which is $1.041 \times 10^{5}$ compared to the intensity of the standard which is $9.871 \times 10^{5}$. The concentration of the standard is $87.7 \mu \mathrm{g} / \mathrm{mL}$. These results verified that Nitzschia culture strains P22C7, P22G9 and KD89 produce domoic acid.

The extracts used for toxin analyses were obtained from cells in 30-days old non-axenic cultures eventhough the average growth cycle for Nitzschia spp. is 7 days (Kotaki et al., 2000; Smida et al., 2014). High levels of DA in the samples could be mainly due to stationery growth phase of cultures where DA production was the highest (Kotaki et al., 2000; Trainer et al., 2012). The extracts also had been left at room temperature for days before LC-MS analyses. It was found that the DA concentration was not affected, meanwhile a very low amount of DA was observed in standard kept in $4^{\circ} \mathrm{C}$. Therefore, temperature could be one of the factors that affect DA concentration. In addition, toxin production had been associated with bacteria where non-axenic cultures produce more domoic acid than axenic cultures (Bates et al., 1995), though presence of bacteria did not necessarily contribute to the toxin production (Douglas and Bates, 1992). Maximum cellular DA contain of toxic Nitzschia spp. ranges from $2 \times 10^{-4} \mathrm{pg}$ cells $^{-1}$ to $15.3 \mathrm{pg} \mathrm{cells}^{-1}$ (Kotaki et al., 2004; Smida et al., 2014). Toxin composition and concentration in toxic Nitzschia sp. differ geographically (Bajarias et al., 2006). Physiological studies on the toxic strains are necessary to obtain more information. 


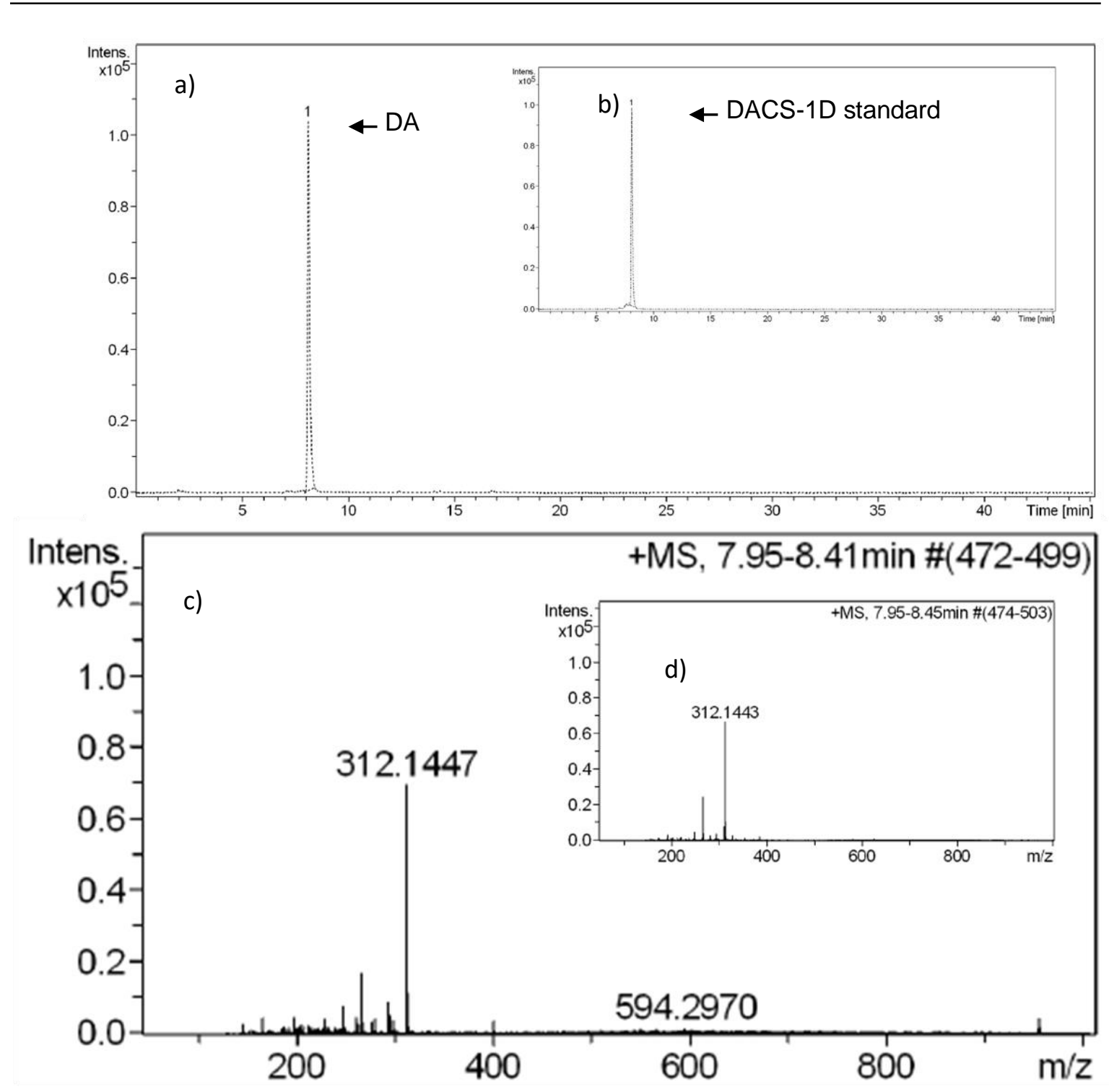

Figure 2. Results of liquid chromatography-mass spectrometry (LC-MS) of P22C7 culture extract against a domoic acid standard of $87 \mu \mathrm{g} / \mathrm{mL}$ (insets). a) Mass chromatogram of DA substance in P22C7 culture extract; b) Mass chromatogram of DACS-1D standard; c) Mass spectrum of DA substance in culture extract scanned at retention time of $8.13 \mathrm{~min}$; d) Mass spectrum of DA substance in DACS-1D standard scanned at retention time of $8.10 \mathrm{~min}$.

\section{CONCLUSIONS AND SUGGESTION}

From this study, we conclude that toxic Nitzschia species are present in Malaysian water. Precautious measure should be implemented to ensure seafood safety, avoid economic losses and to protect estuarine mammals.

\section{ACKNOWLEDGEMENTS}

Suriyanti Su was funded by MyBrain 15 Scholarship of MOHE. Special thanks to Mr.
Alefee Ayatillah from UKM CRIM for LC-MS analyses.

\section{REFERENCES}

Anonymous, Amnesic Shellfish Poisoning (ASP) Toxins: Determination of Marine Biotoxins (Manual). FriedrichSchiller-University, undated). (pp. 42-48).

Bajarias, F. F. A., Kotaki, Y., Relox, J. R., Romero, M. L. J., Furio, E. F., Lundholm, N., Koike, K., Fukuyo, Y., 
\& Kodama, M. (2006). Screening of diatoms producing domoic acid and its derivatives in the Philippines. Coastal Marine Science, 30(1), 121129.

Bates, S. S., Bird, C. J., de Freitas, A. S. W., Foxall, R., Gilgan, M., Hanic, L. A., Johnson, G. R., McCulloch, A. W., Odense, P., Pocklington, R., Quilliam, M. A., Sim, P. G., Smith, J. C., Rao, D. V. S., Todd, E. C. D., Walter, J. A., \& Wright, J. L. C. (1989). Pennate diatom Nitzschia pungens as the primary source of domoic acid, a toxin in shellfish from eastern Prince Edward Island, Canada. Canadian Journal of Fisheries and Aquatic Sciences, 46, 1203-1215.

Bates, S. S., Douglas, D. J., Doucette, G. J., \& Leger, C. (1995). Enhancement of domoic acid production by reintroducing bacteria to axenic cultures of the diatom Pseudonitzschia multiseries. Natural Toxins, 3(6), 428-435.

Douglas, D. J., \& Bates, S. S. (1992). Production of domoic acid, a neurotoxic amino acid, by an axenic culture of the marine diatom Nitzschia pungens f. multiseries Hasle," Canadian Journal of Fisheries and Aquatic Sciences. 49(1), 85-90.

Fritz, L., Quilliam, M. A., Wright, J. L. C., Beale, A., \& Work, T. M. (1992). An outbreak of domoic acid poisoning attributed to the pennate diatom Pseudonitzschia australis. Journal of Phycology, 28, 439-442.

Guiry, M. D., Guiry, G. M. (2014). AlgaeBase. World-wide electronic publication, National University of Ireland, Galway. http://www.algaebase.org; searched on 27 May 2014.

Iwasaki, H. (1961). The life-cycle of Porphyra tenera in vitro. Biological Bulletin, 121, 173-187.

Kotaki, Y., Furio, E. F., Satake, M., Lundholm, N., Katayama, T. , Koike, K., Fulgueras, V. P., Bajarias, F. A., Takata, Y., Kobayashi, K., Sato, S., Fukuyo, Y., \& Kodama, M. (2005). Production of Isodomic Acids A and $B$ as major toxin components of a pennate diatom Nitzschia navisvaringica," Toxicon, 46, 946-953.
Kotaki, Y., Koike, K., Yoshida, M., Thuoc, C. V., Huyen, N. T. M., Hoi, N. C., Fukuyo, Y., \& Kodama, M. (2000). Domoic acid production in Nitzschia Sp. (Bacillariophyceae) isolated from a shrimp-culture pond in Do Son, Vietnam. Journal of Phycology, 36, 1057-1060.

Kotaki, Y., Lundholm, N., Onodera, H., Kobayashi, K., Bajarias, f. F. A., Furio, E. F., Iwataki, M., Fukuyo, Y., \& Kodama, M. (2004). Wide distribution of Nitzschia navisvaringica, a new domoic acidproducing benthic diatom found in Vietnam. Fisheries Science, 70, 2832.

Lundholm, N., \& Moestrup, O. (2000). Morphology of the marine diatom Nitzschia navis-varingica sp. nov. (Bacillariophyceae), another producer of the neurotoxin domoic acid. Journal of Phycology, 36, 11621174.

Perl, T. M., Bedard, L., Kosatsky, T., Hockin, J. C., Todd, E. C. D., \& Remia, R. S. (1990). An outbreak of toxic encephalopathy caused by eating mussels contaminated with domoic acid. The New England Journal of Medicine, 322(25), 1775-1780.

Romero, M. L. J., Kotaki, Y., Lundholm, N., Thoha, H., Ogawa, H., Relox, J. R., Terada, R., Takeda, S., Takata, Y., Haraguchi, K., Endo, T., Lim, P. T., Kodama, M., \& Fukuyo, Y. (2011). Unique amnesic shellfish toxin composition found in the South East Asian diatom Nitzschia navisvaringica. Harmful Algae, 10, 456462.

Romero, M. L. J., Lirdwitayaprasit, T., Kotaki, Y., Lundholm, N., Relox, J. R., Furio, E. F., Terada, R., Yokoyama, T., Kodama, M., \& Fukuyo, Y. (2008). Isolation of ASP toxin-producing Nitzschia from Thailand. Marine Research Indonesia, 33(2), 225-228.

Roy, R. N. (1977). Red tide and outbreak of paralytic shellfish poisoning in Sabah," Medical Journal of Malaysia, 31(3), 247-251.

Scholin, C. A., Gulland, F., Doucette, G. J., Benson, S., Busman, M., Chavez, F. P., Cordaro, J., DeLong, R., De Vogelaere, A., Harvey, J., Haulena, M., Lefebvre, K., Lipscomb, T., Loscutoff, S., Lowenstine, L.J., Marin 
III, R., Miller, P. E., McLellan, W. A., Moeller, P. D. R., Powell, C. L., Rowles, T., Silvagni, P., Silver, M., Spraker, T., Trainer, V., \& Van Dolah, F. M. (2000). Mortality of sea lions along the central California coast linked to a toxic diatom bloom. Nature, 403, 80-83.

Smida, D. B., Lundholm, N., Kooistra, W. H. C. F., Sahraoui, I., Ruggiero, M. V., Kotaki, Y., Ellegaard, M., Lambert, C., Mabrouk, H. H., \& Hlaili, A. S. (2014). Morphology and molecular phylogeny of Nitzschia bizertensis sp. nov. - a new domoic acidproducer. Harmful Algae, 32, 49-63.

Thoha, H., Kotaki, Y., Panngabean, L., Lundholm, N., Ogawa, H., Lim, P. T., Takata, Y., Kodama, M., \& Fukuyo, Y. (2012). Screening of diatoms that produce ASP toxins in Southernmost Asian Waters. Coastal Marine Science, 35(1), 34-38.

Ting, T. M., \& Wong, J. T. S. (1989). Summary of red tides and paralytic shellfish poisonings in Sabah, Malaysia: Biology, epidemiology and management of Pyrodinium red tides, edited by Hallegraph, G. M., \& Maclean, J. L. (ICLARM, Manila) (pp. 19-26).

Trainer, V. L., Bates, S. S., Lundholm, N., Thessen, A. E., Cochlan, W. P., Adams, N. G., \& Trick, C. G. (2012). Pseudo-nitzschia physiological ecology, phylogeny, toxicity, monitoring and impacts on ecosystem health. Harmful Algae, 14, 271-300.

Usup, G., Ahmad, A., Ismail, N. Pyrodinium bahamense var. compressum red tide studies in Sabah, Malaysia: Biology, epidemiology and management of Pyrodinium red tides," edited by Hallegraph, G.M., \& Maclean, J.L. (ICLARM, Manila, 1989) pp. 97-110.

Usup, G., Leaw, C. P., Lim, P. T., Ahmad, A. (2002). Probable toxin producer responsible for the first occurrence of paralytic shellfish poisoning on the east coast of peninsula Malaysia. Malaysian Applied Biology, 31(2), 29-35. 